\title{
SIMON LYRA AND THE LUTHERAN LITURGY IN THE SECOND HALF-CENTURY OF THE REFORMATION IN BRESLAU
}

W

hen exploring the topic of a 'music culture' in a particular city or region, the first task is to examine artefacts, especially the surviving music performed in that location at a particular time. Such an examination will reveal the styles and genres experienced by both the performers and listeners in various contexts. In the case of late sixteenth-century Breslau (now Wrocław) surviving artefacts are remarkably numerous; a significant number of music prints and manuscripts are still extant. In addition, it is especially fortunate that we have a list of recommended works and surviving copies of those works which indicate what was performed. In I593, Simon Lyra was appointed cantor of St Elisabeth's church and school. In that same year, he drew up a list of prints and manuscripts that he considered appropriate for teaching and for use in Lutheran worship. This list provides valuable clues into the musical life of a well-established Lutheran church and school at the end of the sixteenth century.

Simon Lyra (I547-I60I) signed his name 'Simon Lyra Olsnensis', indicating that his place of birth was Öls. I The family name, however, may have been 'Liehr'. ${ }^{2}$ Unfortunately, we do not know anything about his family or where he was educated. ${ }^{3}$ We also do not know exactly when he came to Breslau. In 1578 , he is first mentioned

I Öls (now Oleśnica, Poland) is located 3I kilometers north-east of Wrocław.

2 Georg Jensch, Musikgeschichte der Stadt Breslau, PhD dissertation, Schlesischen Friedrich-Wilhelms-Universität zu Breslau I9I9 (manuscript in PL-Wu). Source: Barbara Wiermann, 'Die Musikaliensammlungen und Musikpflege im Umkreis der St. Elisabethkirche Breslau in kirchliches und bürgerliches Musikleben im Kontrast', in: Early Music - Context and Ideas. International Conference in Musicology. Kraków, I8-2I September 2003, Kraków 2003, pp. 93-I09 at 98. To date, I have not found any reference to a 'Simon Liehr' in any of the standard biographical dictionaries in the past or present.

3 Lyra may have been educated at the Öls Gymnasium, founded in I53O. It is interesting to note that according to the Aeltere Universitäts Matrikeln, ed. Ernst Friedländer, Leipzig I887, vol. I, p. 362, a 'Joannes Lyra Olsnensis' matriculated at the Universität Frankfurt an der Oder in I59I. Perhaps he was Simon's son or another member of the Lyra family in Öls. 
as a member of the faculty of Breslau's St Elisabeth Gymnasium ${ }^{4}$ as a praeceptor. ${ }^{5}$ According to Hanke, in 1578 Lyra already was serving as signator (assistant to the cantor) for the school and the church. ${ }^{6}$ In 1593 , he was appointed cantor upon the death of Erasmus Radewald (I543-93). Lyra served in that office until his own death on 25 February I60I, at the age of 54 .

As cantor he was apparently more dedicated to teaching than to composing, for he left behind only eight of his own works, primarily Latin motets. ${ }^{7}$ Norbert Hampel describes Lyra's compositional style as 'having clear construction, each text phrase is set apart from the preceding and following phrases through sharp contrast. The methods of contrast are: imitative phrases versus homophonic phrases, the full choir versus groups of a few voices, active movement versus rests, and changes in tempo.' ${ }^{8}$ These characteristics are typical of the international Franco-Netherlands style, especially in sacred music.

Lyra's legacy lies in a list of $\mathrm{I} 3$ music prints and manuscripts in the St Elisabeth church music library. According to Johannes Sass, 'We learn what the combined choir [Chorknaben and Choralisten] had to perform, particularly, what kind of songs or what was used for performance, from a music inventory that the St Elisabeth cantor [Simon Lyra] drew up in the year I593.'9 (I have titled this list 'Lyra's Recommended Prints and Manuscripts'). Because we do not have the manuscript in which Sass found the list, any discussion of Lyra's motivation, selection criteria and specific use of the music must remain unknown. After Lyra's list, Sass provides the names of other Breslau signators and cantors found on music manuscripts in the late sixteenth century. Therefore, he concluded that they [...] clearly indicate that the musical works found in the collections were performed by the church choirs.' ${ }^{\prime}$ Sass's only evaluation of the collection is as follows: 'We find in these partbooks a collection of musical works by

The St Elisabeth School was founded as a Trivialschule on I2 August I293 and was elevated to the status of a gymnasium on 29 January 1562. It was the first gymnasium in Breslau.

5 Martin Hanke, Vratislaviensis eruditionis propagatores: id est, vratislaviensium scholarum praesides, inspectores, rectores, professores, praeceptores, tabulis chronologicis comprehensi, Leipzig I7OI. According to Hanke, Lyra served as Praeceptor I in Ordine V (I578-99) and Praeceptor II in Ordine IV (I599-I60I).

6 Ibid. According to Johannes Sass, Lyra succeeded Daniel Büttner, who was signator from I573 to I577, see: Johannes Sass, Die kirchenmusikalischen Aemter und Einrichtungen an den drei evangelischen Haupt-und Pfarrkirchen der Stadt Breslau, PhD dissertation, Schlesischen Friedrich-Wilhelms-Universität zu Breslau I922, p. 20.

7 There are six works in D-Bds Slg. Bohn 15: Christo regi recens nato / Christ der neugebornen König, $5 \mathrm{vv;} \mathrm{Ilicito} \mathrm{castum} \mathrm{Susannae} \mathrm{pectus,} 6$ vv; Omnis anima potestatibus, 6 vv; Veni creator spiritus, 5 vv; Drei schöne Ding sein, $5 \mathrm{vv}$; and Wohl dem, der ein tugendsam Weib hat, $6 \mathrm{vv}$. There are three copies of Rorate coeli desuper in Slg. Bohn I2, I4, and 95. His only printed work is the six-voice motet Ex patre virtutem composed for the wedding of Isaiah Heidenreich and his bride Martha, printed in Breslau by Johannes Scharffenerg in 1580 (PL-WRu 50595 Muz.). On the title page he is identified as 'Simone Lyra, Signat. Vratisl. ad D. Elizab.'

8 Norbert Hampel, Deutschsprachige protestantische Kirchenmusik Schlesiens bis zum Einbruch der Monodie, PhD dissertation, Schlesischen Friedrich-Wilhelms-Universität zu Breslau I937, p. 37.

9 J. Sass, op. cit., pp. I8-I9. Sass only cites 'lose Akten der Kirche St. Elisabeth im Breslauer Stadtarchiv' ('loose documents of the Church of St Elisabeth in Breslau State Archive') as his source. To date, I have not been able to find this source. It was likely destroyed in World War II.

Io Ibid., p. 20. 
the most important masters of the time. 'II Therefore, in my opinion, Lyra's recommendations indicate that he was familiar with the music of his contemporaries, and his list represents the best music for use in St Elisabeth's church and school. As noted above, he started work as signator no later than 1578 and was appointed cantor in 1593 , the year in which (according to Sass) he compiled the list. By I593 he must have had a thorough understanding of the school's curriculum, music's place in the curriculum, and the liturgies of the Church. His compilation of a list of recommended prints and manuscripts may have been the way he established himself as cantor.

I believe that this idea applies equally to six music manuscripts dating from the I580s and I590 that either belonged to him or were collected under his direction. I will discuss this list, titled 'Additional Manuscripts Associated with Lyra and St Elisabeth's, ${ }^{12}$ below.

Taken together, Lyra's repertoire list and the additional manuscripts contain well over a thousand items, including masses, motets, responsories, psalms, passions, Vespers settings and devotional songs. The music in the collections contains all of the items necessary for use in all of the liturgies performed in both the St Elisabeth church and gymnasium in the last quarter of the sixteenth century. The music was written by a large number of composers and, of course, there are a number of individual, personal styles represented. Overall, however, these works display one important characteristic: all of them are in the international Franco-Netherlands style of polyphony described above (a musico-textural, phrase-by-phrase construction; careful attention to clear text declamation; and, to a lesser or greater extent, text painting as an expressive device).

\section{LYRA'S RECOMMENDED PRINTS AND MANUSCRIPTS}

Listed below are Lyra's recommended prints and manuscripts, according to Sass. I have included the full titles, RISM numbers, and the locations and shelf-marks of the extant works.

\section{Cantiones Gregori Langy s und 6 vocum}

According to Sass, this work is Gregor Lange's Cantiones aliquot novae quinque et sex vocum, tum viva voce tum omnis generis instrumentis cantata commodissimae (Frankfurt an der Oder: Andreas Eichhorn, 1580).

RISM A/I: L 583; LL 583. PL-WRu 50543 Muz.

2. Cantus choralis s vocum Joh. Knefely

Johann Knöfel, Cantus choralis, musicis numeris quinque vocum inclusus, eo ordine, quo per totum anni curriculum praecepuis diebus festis in ecclesia cantari solet

II Ibid.

I2 Slg. Bohn 9, I5, 95, 97, 98 and 106. 
(Nuremberg: Theodor Gerlach, I575).

RISM A/I: K 990; KK 990. PL-WRu 50537 Muz.

\section{Opus musicum}

According to Sass, this work is most likely Jacob Handl's Musici operis [Tomus Primus / Secundus Tomus / Tertius Tomus / Quartus Tomus] Harmoniam quatuor, quinque, sex, octo et plurium vocum, quae ex sancto catholicae ecclesiae usu ita sunt dispositae, ut omni tempore inservire queant (Prague: Georg Nigrin, I586-87, I590). RISM A/I: H i980, HH i980; H I891, HH i98I; H i982, HH i982. PL-WRu 505I3 Muz. (three volumes).

\section{Missae Jakoby Handely}

According to Sass, this work is Jacob Handl's Missarum VII. \& VIII. vocum [Liber I, II, III, IV] Selectores quaedam missae, pro ecclesia Dei non intutiles (Prague: Georg Nigrin, I580).

RISM A/I: H 1976, HH 1976; H 1977, HH 1977; H 1978, HH i978; H I979, HH 1979. PL-WRu 50512 I-IV Muz. (all four libri are bound together).

\section{Epithalamion Musicum Joh. Büttneri}

Epithalamion melos. In honorem nuptiarum, Natalitium splendore, virtute eximia literarum, cognitione admirabili amplissimique dignitate exornatissimi Iuvenis Domini Ioannis Butneri Vratislaviensis: Atque pietatis, pudicitiae, formae omniumque virtutum laude eminentissimae. Virginis, Marinae Nobilissimae sapientissimi Viri Domini Nicolai Rhedingeri, Inclytae Reypub. Vratislaviensis Praefecti dignissimi Filiae praeclarae etc. Sex vocibus compositum a Johanne Knefelio Laubano, Illustriss. Principis ac domini, Domini Georgii, ducis Silesiae ac Principis in Liegnitz et Brieg etc. Musici. Adjectum est canticum Sanctorum Ambrosii et Augustini, quinque vocibus compositum, novoque Sponso dedicatum, ab eodem authore. Anno MDLXXIII XIIII decembris, quo felici auspitio nuptiae celebratae sunt. ${ }^{\mathrm{I3}}$

Description by Barbara Wiermann: 'In 30 Blättern, deren letztes leer. Noten, Schrift u. Format gleich den beiden vorigen. Alte Ordnungs-Nummer 4I.

I3 'Wedding song. In honour of the nuptials of the young lord Johannes Bütner of Vratislavia, [who is] adorned by the splendour of his birth, by the exceptional strength of his learning and by his admirable wisdom, [and who is] exceedingly distinguished for his worthiness, and of the most noble and distinguished maiden, well known from the praise given to her piety, modesty, beauty and all her virtues, Marina, daughter of the very wise man Lord Nicolaus Rhedinger, most worthy Prefect of the magnificent Vratislavian Republic. For six voices, composed by Johannes Knefelius Laubanus, musician of the most illustrious prince and lord, Lord George, Duke of Silesia and prince in Liegnitz and Brieg, etc. Added is a song of Saint Ambrose and Saint Augustine, composed for five voices, dedicated to the new bridegroom, by the same author. The year 1573 , the I4th of December, when the nuptials are celebrated under a lucky omen.' The latin texts were translated by the Author. 
Schweinsleder-Bd'. According to Wiermann, this MS is now in the Glinka Museum in Moscow (RUS-Mcm). ${ }^{\mathrm{I}}$

\section{Die deutsche Passion}

This work is probably Joachim a Burck's Die deutsche Passion, Das ist die Historia des Leidens unsers Herrn Jhesu Christi, nach dem Evangelisten S. Johanne in Figural Gesang bracht Durch Joachinum von Burck (Erfurt: Georg Baumann, I573).

RISM A/I: B 4958; BB 4958. PL-WRu 50303 Muz.

\section{Cantionale sive Motetaes und 6 vocum scriptae Dresdae}

Mutetae 6, 5, 4 vocum, scriptae Dresdae Anno (1564). MDLXIIII auf der vorderseite des Einbandes, der innere Titul mit Uncial-Buchstaben: Liber primus Mutetorum sex Vocum ad laudes habendas Jesu Christo, Salvatori nostro, et in gratiam excellentissimi, amplissimi et prudentissimi Reipublicae Wratislaviensis Senatus. Musicis numeris inclusus per Ioannem Sdun. [Johann Sduneck] Illustriss. Principis. Augustini, Electoris Saxoniae. m Musicum Aulicum Dominis Suis Observandissimis. Dulce merum, dulcis cantus, mens conscia recti, Quid tribus his junctis dulcius esse potest. Anno MDLXIIII. Inest liber secundus quinarum Vocum et tertius quatuor vocum. ${ }^{\text {Is }}$

\section{Te deum laudamus 5 partes in folio}

For this work there are two possibilities:

a. Johann Knoefel's Te Deum laudamus included in his Epithalamion melos, or

b. S. Ambrosii et Augustini Canticum: Te deum laudamus etc. Sex et quinque Vocum. ${ }^{16}$

I believe that S. Ambrosii et Augustini Canticum (b) is the more likely possibility for this work for two reasons: I) it is listed as a separate work (rather than a part of another work) in Lyra's recommended prints and manuscripts and 2) the 'alte Ordnungsnummer' is 42 , which indicates that it was once catalogued alongside

I4 B. Wiermann, op. cit., p. IO4.

I5 'First book of motets of six voices in praise of Jesus Christ our saviour and in thanks to the most excellent, distinguished and prudent Senate of the Vratislavien Republic. Included with musical numbers by Johann Sduneck, Court Musician of the most illustrious prince Augustine, Elector of Saxony, with his attendant lords. Sweet wine, sweet song, a mind conscious of righteousness, What could be sweeter than these three things together. In the year I564. The second book contains [motets] of five voices and the third book contains [motets] of four voices.'

Description in D-Bds Mus. Ms. Theor. Kat. I66: 'IIs Blätter Pagier; Text u Titel-Noten u Schrift, wie sub b u c worher; - größtes Folio, gepreßter schwarz lederband / alte Ordnungs Nr. 40'. According to Barbara Wiermann (op. cit.), this MS is now in the Glinka Museum in Moscow (RUS-Mcm).

I6 Description by Barbara Wiermann (op. cit.): 'in ganzen, geschwärzten, halben u. Viertel-Noten - in 20 Pergamentblättern des größten Folio, bezeichnet nach Bogen mit rothen griech. Schriftzeichen a - initus $\aleph$ br. Perg. Umschlag_-halb mit einer alten Ordnungsnummer 42 versehen'. According to Wiermann, this MS is now in the Glinka Museum in Moscow (RUS-Mcm). 
the Mutetae 6, 5, 4 vocum, scriptae Dresdae (alte Ordnungsnummer 40) and the Epithalamion melos (alte Ordnungsnummer 4I).

\section{Thesaurus Noricus}

According to Sass, this work is Johann vom Berg (ed.), Thesaurus musicus continens selectissimas octo, septem, sex, quinque et quatuor vocum Harmonias, tam a ueteribus quam recentioribus Symphonistis compositas, \& ad omnis generis instrumenta Musica accommodatas (Nuremberg: Johann Berg and Ulrich Neuber, I564). RISM B/I.I: I564/I. PL-WRu 50206 Muz.

\section{IO. Thesaurus Venetianus}

According to Sass, this work is Petro Joannello Bergomensi de Gandino (ed.), Novi Thesavri mvsici qvo selectissime planeq; noue nec unquam in lucem edite cantiones sacrae (quas vulgo moteta vocant) continentur octo, septem, sex, quinque ac quatuor vocum, a prestantissimis ac huius aetatis, precipuis Symphoniacis composite, que in sacra Ecclesia catholica, summis solemnibusque festivitatibus, canuntur, ad omnis generis instrumenta musica, accommodate (Venice: Antonio Gardano, I568). RISM B/I.I: I568/2. PL-WRu 50207 Muz.

\section{Cantionale Hieronymi Hannolt ${ }^{7}$}

I2. Aliud Cantionale continens unam melodiam 'Te deum laudamus'

This work is probably Jacob de Kerle's Te Deum laudamus (5 vv), D-Bds Slg. Bohn I58.

\section{I3. Aliud continens Missam super Benedicta Philippi de Monte}

According to Sass, this work is Missa super Benedicta coelorum regina by Philippe de Monte (6 vv), Slg. Bohn I75. According to Barbara Wiermann, it now is in Russia (RUS-Mcm Ms. mus. I75). ${ }^{18}$

I7 At this point, I am unable to identify this work. Hieronymus Haunold (I5I8-67) studied at the universities of Frankfurt an der Oder, Wittenberg and Leipzig. He was a medical doctor and a member of the Liegnitz city council. His second wife, whom he married in I554, was Magdalena von Jenkwitz, daughter of Nikolaus von Jenkwitz (I486-I537). Nikolaus studied at the St Elisabeth School and the University of Wittenberg. He was a member of the Breslau city council from 1520 to 1537 , where he served as assessor and consul; he also served a term as Landeshauptmann (governor) of the Republic of Breslau.

I8 B. Wiermann, op. cit., p. 98. 


\section{ADDITIONAL MANUSCRIPTS ASSOCIATED WITH LYRA AND ST ELISABETH'S}

In addition to the prints and manuscripts listed above, there are five manuscripts owned and probably used by Lyra and one manuscript that contains works by him. In the descriptions, I have identified the number of works by Gregor Lange, Johann Knoefel and Jacob Handl as well.

I. Slg. Bohn 9 (I580), six partbooks in quarto. 'S[imon] L[yra] O[lsnensis] I580' is written on the front covers. This contains 23 works by composers such as Gregor Lange, Orlandus Lassus, T.L. de Victoria, Clemens non Papa, Jacob Meiland and Joachim Belitz. All of the motets are in Latin except for Lange's only contribution: Der Ehlich standt ist lobeswerd / Drum wünschn wir breutigam vnd Braut. D-Bds Slg. Bohn 9.

2. Slg. Bohn is ( 1587 ), five partbooks in quarto. Works by Simon Lyra (six), Gregor Lange (32), Johann Knoefel (four) and Jacob Handl (48); 3I5 works in total. Written by various hands. On the first page of the D partbook, 'Simon Lyra Cantor' is written in hand in large letters. The rest of the page is a handwritten explanation of $b$ rotundum, $b$ quadratum, the meaning of the sharp sign and the chromatic genus. The authorities cited at the bottom of the page include Plutarch and Boethius. On the first page of the B partbook, 'Simon Lyra Signator ad D. Elisab. Olsnensis' is written. On page 3 of the B partbook is written 'Lusus fortuna variatur imagine Luna Crescit decrescit constans consistere nescit'. ${ }^{9}$ Next to it is an undecipherable signature. Beside work number I7 (Tant vous alez doulz guillemette) is written 'Scribebat Carolus du Quesne alias de Quercu Olsnensis, Vratisl.: Ao I587. 4 Februarij'. Also in the B partbook next to work number $2 \mathrm{I} 7$ (Ich armer mensch gar nichts bin by Simon Fidler) is a dedication to Simon Lyra. D-Bds Slg. Bohn I5.

3. Slg. Bohn 95 (Bohn: end of the sixteenth century), one volume in large folio (choirbook). Fol. Iv: 'Missale sive Cantionale in qvo continentvr Officia per integrum annum in summis festivitatib. Decantanda'. ${ }^{20}$ Fol. 2 r: 'Officia per integrvm annvm in svmmis festivitab. Decantanda'. ${ }^{21}$ Fol. 3 r: 'In laudem D.O.M. conscriptum'. Fol. 3v: 'Ampliss: Senatvi Vratislaviensi dedicatvm'. Works by Lyra (I), Knoefel (7) and Lange (2), ${ }^{22}$ ( 15 works in total). The current location of this manuscript is unknown.

4. Slg. Bohn 97 (I593), six partbooks in quarto. One mass by Handl and 4I masses by various composers, including Orlando di Lasso, Philippe de Monte, Jacob

I9 'The game of fortune varies like the moon; it waxes and wanes, always unable to stand still.'

20 'Missal or songbook in which the offices for the whole year, to be sung at the highest festivities, are assembled.'

2I 'Offices for the whole year, to be sung at the highest festivities.'

22 These two works, the introits Puer natus est nobis et filius datus for five voices and Puer natus est nobis for four voices, are not duplicates of any work in his printed collections. Perhaps they are unpublished unica. 
Regnart and Jacob Vaet. In the D partbook, 'Simon Lyra Olsnensis' is written on fol. Ir. At the end of work number I is written 'Finis. Anno I593 23 Martij. Joh: Rotth. Namsl. S.' At the end of work number 2 is written 'Scribebat Johannes Rosth Namslaviensis. Anno 93. I7 Maio.' D-Bds Slg. Bohn 97.

5. Slg. Bohn 98 (I597), eight partbooks in quarto. One mass by Handl, I6 masses, six Magnificats and three motets by many of the same composers as in Bohn 97. 'S[imon] L[yra] O[lsnensis] 1597 ' is written on the front covers. Beside work number 16 is written ' 1594.2 Mai'. D-Bds Slg. Bohn 98.

6. Slg. Bohn 106 (I594), five partbooks in folio. Is Magnificats (three by Knoefel), four settings of Dixit Dominus domino meo (in five different modes), and nine introits for nine major feasts starting with Advent, all composed by Blasius Ammon. 'S[imon] L[yra] O[lsnensis] 1594 ' is written on the front covers. D-Bds Slg. Bohn Io6.

One interesting aspect of Lyra's list of recommended prints is that the first five items were written by three composers: Gregor Lange, Johann Knoefel and Jacob Handl (see pp. 5-7). I will discuss this feature in a separate section below.

\section{THE MANUSCRIPTS AND PRINTS: POSSIBILITIES AND CHOICES}

When studying collections of prints and manuscripts, I believe it is helpful to make a distinction between two types of use. Printed music represents possibilities. In other words, they are collections from which a cantor could make choices. In Lyra's case, we don't know when, where or for what occasion any of the recommended printed works were performed. Therefore, we can view Lyra's recommendations as general examples of what he considered liturgically and aesthetically appropriate for his time and position.

The prints in Lyra's list contain every musical item necessary for all of the liturgies celebrated in St Elisabeth's church and for teaching in the gymnasium. Lange's Cantiones is a collection of I9 motets setting various Proper texts for five and six voices. Knoefel's Cantus choralis contains 5-voice settings of introits, troped Kyries, Glorias and prosas for Advent, Nativity, Epiphany, the Resurrection, Ascension, Pentecost and Trinity. The settings for Nativity include a German-texted prose - Dancksagen wir alle - in addition to the traditional Latin Grates nunc omnes. At the end of the print are settings of the Te Deum laudamus for five voices, Serva Deus verbum tuum for six voices and Da pacem Domine for six voices. Handl's three-volume Opus musicum contains 230 motets (for four to eight voices) for all of the major feasts plus several minor feasts, such as the Division of the Apostles and the Dedication of a Church. Handl's four-volume Missae has I6 settings of parodied masses based on Latin- and German-texted works. Thesaurus musicus and the Novus Thesaurus musicus are the two most well-known and widely distributed anthologies produced in the 1560 . They contain several hundred works for 4-I2 voices by a large number of 
the finest first-generation composers of the high Renaissance, beginning with Josquin. The other recommended works contain motets for special occasions, settings of the Te Deum, a parody mass, and music for Vespers. The prints also display some evidence of use; in all of the extant copies except one there are note corrections and underlining beneath a few texts. ${ }^{23}$

On the other hand, manuscripts represent choices. The musical works in the six Bohn manuscripts associated with Lyra are the result of specific decisions to copy and place them in particular collections in a particular order. Therefore, they can provide clues as to what works were performed on which occasions. In other words, manuscripts provide a truer picture of a musical culture in a particular location. In this case, someone, perhaps Lyra himself, made the decision to transcribe 420 individual works by hand.

Of the manuscripts, Slg. Bohn I5 is by far the largest of the six, with 315 works in total. It is the most comprehensive of the manuscripts, containing masses, Vespers responsories, Latin motets, sacred songs in German, and occasional works such as wedding motets. Only parts of Slg. Bohn Is are organised. The first five works are unnumbered (four sets of Vespers responsories and a mass by Regnart). Numbers I-II are collected under the heading 'Die Nativitatis Christi'. Numbers I2-196 are a miscellaneous collection of motets in Latin and German, masses, introits and occasional works. Numbers 197-215 are 19 introits by Blasius Ammon. ${ }^{24}$ Numbers 216-305 are another miscellaneous collection of motets, masses and songs. The manuscript concludes with five introits. According to the scribal annotation next to work number 17, the earliest date for the manuscript is 1587, when Lyra was signator at St Elisabeth's. It is not known when the manuscript was completed before 1592, when Lyra was signator, or during his tenure as cantor. It is reasonable to assume, however, that Lyra supervised the creation of the collection.

It is interesting to note that thirty of the motets in Slg. Bohn 15 are by Lange, forty seven are by Handl and four are by Knoefel. Despite the fact that apparently there is no comprehensive organisation of the types of works in the manuscript, most of the works by these three composers appear in groups. Numbers 2-27 contain thirteen motets by Lange and one by Handl. Numbers 3I-68 contain three motets by Lange and seventeen by Handl. Numbers $87-98$ contain thirteen motets by Handl. Numbers I32-I40 contain three works by Knoefel and three by Simon Lyra. Numbers $165-174$ are all by Handl. Numbers $227-248$ contain nine works by Lange and one by Handl. 25

23 However, the note corrections could have been made when those parts were transcribed in the manuscripts.

24 Ammon (c.1560-90) was a monk and cantor at several Franciscan and Cistercian monasteries. The source of these introits is his Liber sacratissimarum quas vulgo introitus appellant cantionum selectissimus, 5vv (Vienna I582).

25 It would be interesting to compare these works with their printed versions. Perhaps it will reveal patterns of choices. However, that is a project for another day. 
In addition to the motets, Slg. Bohn I5 contains nine masses by five named composers: Jacob Regnart (2), Giuseppe Guami (I), Orlando di Lasso (2), Lange (I) and Thomas Crecquillon (I). The composers of two of the masses are unknown. The first two masses, both by Regnart, are complete, containing all five parts of the Ordinary. Of the remaining seven, six (by Guami, Lasso, Lange and the unidentified composers) consist only of the Kyrie and Gloria movements, and one (by Crecquillon) contains all of the movements except the Gloria.

In contrast to Slg. Bohn I5, the other five manuscripts are more clearly organised.

Slg. Bohn 95 contains three sets of introits, masses, and prosas (sequences). Set one, numbers $\mathrm{I}-6$, is for Nativity. There are four introits, a mass (Kyrie and Gloria movements only) and a prosa. All of the compositions are by Lyra (I), Knoefel (3) or Lange (2). Set two, numbers $7-9$, is titled 'Off. de Resurrectione'. It contains an introit by Johann Galliculus, a mass (Kyrie paschale and Gloria only) by Knoefel and a prosa by Knoefel. Set 3, numbers IO-I3, is titled 'Officium de S. S.' It contains two introits, an alleluia and a prosa. The only named composer in this set is Knoefel. Number I4 is a setting of Benedicta sit sancta Trinitas by Knoefel. Number I5 is a setting of the Te deum laudamus by Jacob de Kerle.

Slg. Bohn 97 and 98 contain the largest number of masses: 58 . None of the named composers in Slg. Bohn 97 are by Lange, Knoefel or Handl. In Slg. Bohn 98, one of the masses is identified as being composed by Handl. 55 of them are parody masses and only three have generic names: two are masses in the sixth and seventh modes (both by Philippe de Monte), and the third, by Stefano Felis, is titled Missa Sancti Nicolaj. Both manuscripts also contain a few Latin motets and Magnificats. What is most interesting about these two collections is that most of the masses are lacking one or more of the Ordinary texts. Only four contain settings of all the texts of the Ordinary. Twelve have only the Kyrie and Gloria, and 39 lack only the Credo. Of the remaining three masses, two lack the Credo and one other movement. All of the masses from which these copies were made contain settings of the complete Ordinary texts. In other words, the mass movements in Slg. Bohn 97 and 98 are the result of choices made by an individual (as noted above, either Lyra himself or someone at his direction). I believe that the contents of the two manuscripts provide strong evidence that no later than the early I590s parts of the Ordinary, beginning with the Credo, had begun to be replaced by vernacular songs sung by the congregation.

The first half of Slg. Bohn 106 is undoubtedly a Vespers collection. There are I3 Magnificats (by Orlando di Lasso, Jacob Reiner, and Knoefel) for four, five and eight voices, one responsory (by an unidentified composer), a Domine ad adjuvandum me setting by Giovanni Matteo Faà di Bruno ${ }^{26}$ and a setting of Dixit Dominus Domino meo

26 Most likely from his Salmi di David profeta con tre magnificat, et altri componimenti a cinque, sei, et otto voci (Venice 1573 , second edition Brescia 1587 ). 
in falsobordone. The last nine works are all introits by Blasius Ammon for various feast days and seasons (Nativity, Advent, Pentecost, Trinity, St Michael the Archangel, etc.). ${ }^{27}$

Taken together, the five manuscripts contain 425 polyphonic settings of everything a cantor and choir would need in the Sunday and feast day liturgies for the entire church year. The composers are predominantly central European, along with a few Italians, and many were still living and publishing at the time.

In order to explore fully the idea that the relationship between prints and manuscripts consists of possibilities and choices, it is necessary to compare all of the compositions in the manuscripts to those in the prints. According to my brief comparison by title alone between the manuscript and printed works of Lange, Knoefel and Handl, very few of the manuscripts contain copies of printed works. ${ }^{28}$

GREGOR LANGE, JOHANN KNOEFEL AND JACOB HANDL

As previously noted, one rather interesting aspect of Lyra's list of recommended prints is that the first five were written by Gregor Lange, Johann Knoefel and Jacob Handl. All of them, except for Knoefel's Cantus choralis, were published when Lyra was working at St Elisabeth as signator. In addition, all three are well represented in the manuscripts associated with Lyra and St Elisabeth, especially in Slg. Bohn I5. This raises some intriguing questions. Why are these three composers so prominent? Is it possible that Lyra knew them and their music personally or professionally?

Lange (c.1540-87) became cantor and organist for the University of Frankfurt an der Oder in I574. Unfortunately, he apparently contracted an incurable illness about I580 and had to resign his position shortly thereafter. From 1583 until his death on I May 1587 he lived in Breslau, supported by the city council. Both the 1580 Cantiones and the 1584 Liber secundus cantionum sacrarum are dedicated to the council. ${ }^{29}$

Knoefel (c.1525-c.1617) was born and educated in Lusatia. In 1569, Duke Heinrich of Silesia, Liegnitz, Brieg and Goldberg appointed him as his court Kapellmeister. Because Liegnitz is quite close to Breslau, he likely knew Breslau's church, school and civic musical organisations and personnel, including Lyra. For example, Knoefel's Epithalamion melos, as noted above, is a six-voice motet for the wedding of Johann Büttner, one of Breslau's city council members, to Maria Rhedinger, a member of one of Breslau's leading patrician families. By the mid I570s, however, Knoefel apparently knew that political trouble was brewing for the duke, and he began looking for another position. To do this, he used the time-honoured method of dedicating printed music to a head of state or the ruling council of an independent city. In I575, he dedicated to Breslau

All of these introits are also in Slg. Bohn I5 (numbers 197, 198, 199, 200, 201, 208, 212, 213 and 214).

As noted in footnote 25 , such a study is a project for another day.

29 In addition, Lange wrote wedding motets for two Breslau patricians - Heinrich Schmidt (I584) and Johannes Hennmann (I586) - and a four-part strophic song dedicated to Breslau City Council (I585). 
city council his Cantus choralis, a collection of homophonic/homorhythmic versions of the Proper chants (introits, alleluias and sequences) and some Kyries and Glorias for the major feasts of the church year. Despite the dedication and his connections, however, he was not offered a position in the city. He remained in Silesia until 1580, when he was appointed by the Palatine Elector Ludwig VI to direct his court chapel in Heidelberg. Thus, Knoefel's and Lyra’s time in Breslau overlapped for at least two years.

Handl (I550-9I) was born in Slovenia. In his mid teens he left his hometown and began a life of travel and study through Austria, Moravia, Silesia and Bohemia, ending in Prague, where he died in I59I. On his journeys he became acquainted with a number of influential clergymen, especially abbots and bishops, to whom he dedicated his printed compositions. His time in Breslau and its neighbouring cities was especially productive. In Breslau he came in contact with archbishop Andreas Jerin and Stanislav Pavlovsky, then a canon at the cathedral. Handl lived in or around Breslau from the mid 1570 s to about 1580, when he was appointed choirmaster to Pavlovsky, who had become bishop of Olomouc. ${ }^{30}$

Because Lyra came to Breslau no later than 1578 , he and Handl would have been in the city together for at least a year or two. We know that Handl composed masses and motets during his time there. According to Marc Desmet,

[...] at least part of Handl's later published works may have been conceived in Silesia. This is especially true of the masses, the edition of which in 1580 making obvious a completion of the volume in Silesia, during the months which preceded the printing process. But this is equally true of a significant part of the motets published in the vast Opus musicum collection, motets for which we find manuscript copies circulating in Silesia before their date of publication in Prague. ${ }^{3 \mathrm{~T}}$

Although there is no extant documentary proof that Lyra, Lange, Knoefel and Handl knew each other in the I570s and I580s, I believe that the circumstances of their lives and careers support the possibility that Lyra's choices of repertoire for the church and school of St Elisabeth were based, at least partially, on his personal and/ or professional relationships with the three composers. Of course, reasons other than personal relationships, such as geographical proximity, could have influenced Lyra's decision to feature their works. At this point in time, however, I have not identified any particular cultural, regional or political reasons behind Lyra's choices.

30 Handl honoured these relationships when he dedicated Book I of Opus musicum to archbishop Jerin and bishop Pavlovsky, in addition to the archbishop of Prague. Of course, we do not know the precise nature of his relationships with Jerin and Pavlovsky, although it is likely that they were Handl's patrons or that he desired them to be his patrons.

3I Marc Desmet, 'Jacob Handl's Compositions Preserved in the Brzeg Manuscript Collection: Presentation and Chronological Clues', in: The Musical Culture in Silesia before 1742: New Contexts - New Perspectives, eds. Paweł Gancarczyk, Lenka Hlávková-Mráčková, and Remigiusz Pośpiech, Frankfurt am Main 2013 (= Eastern European Studies in Musicology I), p. II7. One example that supports Desmet's point is that in Slg. Bohn 15 , Handl is the most represented composer, with 48 works. 


\section{WHAT DO LYRA'S RECOMMENDATIONS TELL US ABOUT MUSIC}

\section{IN THE ST ELISABETH LITURGIES?}

The establishment of the Reformation in Breslau in the early I520s did not result in radical changes to the liturgies and the accompanying music. The early church leaders Johannes Hess (I490-I547), pastor of St Maria Magdalena, and Abrosius Moibanus (I494-I554), pastor of St Elisabeth - followed Luther's advice that no sudden changes should be made in the liturgy, in order to not upset those whose faith was weak. Only the parts of the service considered theologically objectionable were removed or changed. Hess agreed with Luther that once these items were altered or removed, the rest of the traditional services could be retained if they were helpful to the spiritual life of the people..$^{32}$ For this reason, he was cautious and careful when reforming the liturgies at St Maria Magdalena. ${ }^{33}$

According to Lothar Hoffmann-Erbrecht, there were few changes in the liturgies, and beloved musical traditions were kept, such as Latin-texted polyphonic music, plainsong and the continuation of the Nebengottesdienste: Matins, Lauds and Vespers. ${ }^{34}$ In the sixteenth century, masses celebrated at St Elisabeth conformed to Luther's Order of Mass and Communion for the Church at Wittenberg, which is entirely appropriate for churches with attached Latin schools and university churches at which Latin was a common language. ${ }^{35}$ With the exception of perhaps a few congregational songs or a sermon in German, the services in Breslau were not conspicuously Lutheran from the beginning.

It is commonly assumed that what we consider to be a distinctly Lutheran service, characterised by the congregational singing of monophonic chorales, developed very early in the Reformation due to Luther's strong advocacy of congregational participation in the liturgy and his composition of some of the earliest sacred songs in German. Additionally, this concept included German composers using chorales as cantus firmi in polyphonic settings. These 'chorale motets' became the choral contribution to the Lutheran service, replacing the Latin motet. These ideas, however, are not entirely accurate. According to Joseph Herl,

[In nineteenth-century academic studies of German Reformation liturgy and hymnody], scholars assumed that hymns had the same function in early Lutheranism as in their own time; that is, as songs intended for and sung by congregations. Sometimes a researcher would notice that the liturgy in a particular locality was sung almost entirely by the choir, but this would be regarded as an exception. Until recently, no one questioned the received notion that the early Lutheran liturgy was essentially congregational in nature and that hymns sung by the people were an outstanding feature of that liturgy.

See Martin Luther's An Order of Mass and Communion for the Church at Wittenberg, 1523 in Luther's Works, vol. 53, Liturgy and Hymns, Philadelphia 1965, pp. 19-40, especially 36-39.

33 David Erdmann, Luther und seine Beziehungen zu Schlesien, insbesondere zu Breslau, Halle 1887, pp. 27-28.

34 Lothar Hoffmann-Erbrecht, Musikgeschichte Schlesiens, Dülmen I986, p. 59.

35 In the Order for Mass and Communion Luther did, however, commend the congregational singing of vernacular hymns as substitutes for some Ordinary and Proper texts and after Communion. 
Yet the evidence [...] shows that the break with the past was not nearly so complete. [...] The transition from a choral to a congregational service was a gradual one, occurring over a period of about two hundred fifty years, with bumps and starts in the process as churches tried at various times to accommodate various proponents of both choral and congregational liturgies. ${ }^{36}$

Herl concluded that: '[...] although the people sang to some extent in sixteenthcentury Lutheran churches, it was nonetheless a long time before they took ownership of the liturgy and the Lutheran Church became truly "the singing church". 37

In Deutschsprachige protestantische Kirchenmusik Schlesiens bis zum Einbruch der Monodie, Norbert Hampel states that, in Breslau, until the I570s choirs sang only Latin masses and motets and that German-language music was restricted to monophonic congregational singing. His research suggests that until $c$. I570, Breslau's Lutheran churches, especially those with attached school or cantor choirs, followed the liturgy established by Martin Luther in the Formula Missae of I523. During this time, German-texted music was restricted to hymns sung by the people, beginning with the Breslauer Gesangbuch of I525. Polyphonic German songs and German-texted motets entered the repertory in the I570s and only gradually supplanted the Latin mass and motet in a process that took decades to complete. ${ }^{38}$

I believe that Simon Lyra's recommended prints and manuscripts and the manuscripts associated with him support Herl's and Hampel's ideas. The recommended prints and manuscripts, with the exception of Die deutsche Passion, contain exclusively Latin masses and motets by composers from the turn of the sixteenth century to 1587 . The earliest composers, active in the first half of the sixteenth century, are represented in the anthologies Thesaurus musicus and Novus Thesaurus musicus. The other composers were active in the 1570 and 1580 .

The additional Bohn manuscripts (Slg. Bohn 9, I5, 95, 97, 98, and 106), dating from I580 to I597, are more varied in their contents. Slg. Bohn 9, with one exception, contains only Latin motets. The largest manuscript, Slg. Bohn I5, contains only forty German-texted works and one French-texted work. The vast majority of the total (315) are Latin motets. As noted above, six of the Is masses lack one or more texts of the Ordinary. This is quite a low number of masses for which German-language sacred songs (either monophonic or polyphonic) are intended to substitute for the missing movements.

Aside from two Latin motets, Slg. Bohn 95 consists of three sets of what have been called 'missa brevi' or 'Lutheran' masses: introit, Kyrie and Gloria, and prosa. As noted above, Slg. Bohn 97 and 98 contain 58 masses, most of which are lacking

36 Joseph Herl, Worship Wars in Early Lutheranism: Choir, Congregation, and Three Centuries of Conflict, Oxford 2004, pp. 176-I77.

37 Ibid., p. I79.

38 N. Hampel, op. cit., p. 17. 
one or more of the standard Ordinary texts. Slg. Bohn Io6 is a collection of Vespers texts and a set of introits.

According to my analysis of Lyra's recommendations, by the time he arrived at St Elisabeth, the liturgies, especially the mass, still followed Luther's Latin Formula Missae, adopted in the $1520 s$. The music for the services consisted of Latin masses and motets by the most highly regarded, international composers of the first half of the sixteenth century. During his time as signator and cantor, he updated the church and school choir repertoire with music by his contemporaries, primarily composers from Central Europe. Three of those composers, Gregor Lange, Johann Knoefel and Jacob Handl, may have been his friends and/or colleagues. In addition, some of the manuscripts collected under his direction provide evidence that the Breslau liturgies were beginning to change in the direction of the seventeenth-century Lutheran service in which the 'Latin choir' gave way to more German-texted sacred music and greater congregational participation.

There are a number of reasons why directors of musical organisations choose repertoire: liturgical occasion, the appropriateness of a text, the musical abilities of the group, available resources, available preparation time, pedagogical potential or a desire to keep up with contemporary taste. Lyra likely based his repertoire choices on these reasons as well as on desires to update the repertoire, personal relationships, such as those with Lange, Knoefel and Handl, and the theological movement to shift the emphasis of the mass toward more congregational participation in worship.

In my opinion, Lyra's work as signator and cantor at St Elisabeth embodied all of these characteristics. As a result, his church and school maintained a rich liturgical and pedagogical life as a significant parish church in an imperial city. Musically, the services at St Elisabeth would have ranged from sumptuous to serious and solemn, and everything in between. And I suspect Martin Luther, that lover of good music, would have been very pleased.

\section{SIMON LYRA I LUTERAŃSKA LITURGIA W DRUGIM PÓEWIECZU REFORMACJI WE WROCŁAWIU}

W I593 r. Simon Lyra (I547-I60I) został kantorem kościoła i gimnazjum św. Elżbiety we Wrocławiu. W tym samym roku sporządził listę druków i rękopisów, które uznał za najodpowiedniejsze do nauczania i sprawowania luterańskich nabożeństw. Oprócz tej listy istnieje sześć rękopisów muzycznych z lat osiemdziesiątych i dziewięćdziesiątych XVI w., albo do niego należących, albo skompilowanych pod jego nadzorem. W sumie na liście Lyry oraz w tych dodatkowych manuskryptach znalazło się ponad tysiąc utworów, w tym msze, motety, responsoria, psalmy, pasje, nieszpory i pieśni nabożne, które dostarczają cennych wskazówek na temat życia muzycznego w kościele i gimnazjum św. Elżbiety ostatniej ćwierci XVI w., będąc zarazem świadectwem muzyki społeczności luterańskich tych czasów. 
Autor uważa, że badając kolekcje druków i rękopisów, należy rozróżnić dwa rodzaje ich użytkowania. Drukowane edycje muzyczne ukazują możliwości - są to bowiem zbiory, z których kantor czerpał repertuar, dokonując określonych wyborów. W przypadku Lyry możemy zauważyć, jakie kolekcje uważał on za odpowiednie pod względem liturgicznym i estetycznym dla jego czasów i potrzeb wyznaczanych przez sprawowaną przez niego funkcję. $\mathrm{Z}$ drugiej strony manuskrypty reprezentują wybory. Pojawienie się określonych utworów muzycznych, w ustalonym porządku w sześciu rękopisach związanych z Lyrą (pochodzą one z kolekcji Bohna) jest świadectwem konkretnych decyzji repertuarowych. Mogą one dostarczyć wskazówek jaka muzyka była wykonywana i przy jakiej okazji. Innymi słowy, manuskrypty dają dokładniejszy obraz kultury muzycznej danego ośrodka.

Na podstawie analizy rozumianych w ten sposób zaleceń Simona Lyry można dojść do wniosku, że w czasie, gdy objął on posadę przy kościele św. Elżbiety, liturgia, a zwłaszcza msza, wciąż stosowały się do łacińskiej Formula Missae Marcina Lutra zaadoptowanej w latach dwudziestych XVI wieku. Muzyka do nabożeństw składała się z łacińskich mszy i motetów najwybitniejszych kompozytorów europejskich I poł. XVI wieku. Jako signator i kantor Simon Lyra zaktualizował repertuar wokalny w kościele i w szkole, wprowadzając do niego muzykę kompozytorów swojej generacji, głównie z Europy Środkowej. Z trzema z nich - z Gregorem Lange, Johannem Knöfelem i Jacobem Handlem - mógł on pozostawać w osobistych kontaktach. Ponadto niektóre rękopisy spisane pod nadzorem Lyry dowodzą, że liturgia we Wrocławiu zaczęła przejmować cechy właściwe dla XVII w., kiedy to „chór łaciński” ustąpił miejsca muzyce sakralnej z tekstami niemieckimi, z większym udziałem śpiewu kongregacji.

Redakcja

Keywords / słowa kluczowe: St Elisabeth Gymnasium in Wrocław / gimnazjum św. Elżbiety, St Elisabeth church in Wrocław / kościół św. Elżbiety we Wrocławiu, musical manuscripts / rękopisy muzyczne, repertoire of Lutheran services / repertuar nabożeństw luterańskich, Bohn's collection / kolekcja Bohna

\footnotetext{
Allen Scott, PhD, is Professor of Music History in the Greenwood School of Music at Oklahoma State University. In 20I0-20II he taught at the Musicology Institute of the University of Wroctaw as a Fulbright scholar. At Oklahoma State University, Professor Scott teaches undergraduate music history courses, Introduction to Research in Music, graduate music history seminars, and the history of opera. He received the $\mathrm{PhD}$ in Historical Musicology from Florida State University and the M.M. in Musicology from the University of Alabama.
} 